\title{
Çocukluk çağı alopesi areatalı olgularımızın geriye dönük değerlendirilmesi
}

\author{
Retrospective evaluation of childhood alopecia areata cases
}

Munise Daye, Seda Doğan, Șükrü Balevi, İnci Mevlitoğlu

Necmettin Erbakan Üniversitesi Meram Tıp Fakültesi, Deri ve Zührevi Hastalıklar Anabilim Dalı, Konya, Türkiye

\section{Özet}

Amaç: Alopesi areata (AA)'Iı olguların yaklaşık \%20'si çocuklardır. Çocukluk çağında görülen alopesi areata ile ilgili sınırlı bilgi bulunmaktadır. Kliniğimizde takip edilen AA'lı çocuk olguların demografik özelliklerini, hastalık tedavilerini ve takiplerini incelemeyi amaçladık.

Gereç ve Yöntem: Yaşları 16 ve altında olan 110 AA hastasına ait veriler geriye dönük olarak incelendi. Yaş, cinsiyet, hastalık başlangıç yaşı, hastalık süresi, AA tipi ve başlangıç yeri, tırnak tutulumu, eşlik eden dermatoz veya sistemik hastalık varlığı, laboratuvar testleri, AA tedavileri ve takip edildikleri döneme ait bilgiler değerlendirildi.

Bulgular: Olguların \% 46,4'ü kadın, \%53,6'sı erkekti. Yaş ortalamaları 10,35 yıılı. Hastalık başlangıç yaşı 8,65 yıldı. AA başlangıç yeri \% 83,6 olguda scalp, \% 5,4 olguda kas, \%5,4 olguda vücut kilları, \%2,7 olguda kirpik, \%2,7 olguda kas ve kirpikti. Hastalık tutulum tipi \%73,4 olguda AA, $\% 19$ olguda alopesi totalis, $\% 5,4$ olguda alopesi üniversalis, $\% 1,8$ olguda ofiyazisti. Tırnak tutulumu $\% 36,3$ olguda mevcuttu. Nevüs flammeus \%2,7 olguda mevcuttu. Hastalık süresi ortalama 17,02 aydı. Eşlik eden dermatoz $\% 2,7$ olguda vitiligo, \%6,3 olguda atopik dermatitti. Eşlik eden sistemik hastalık \%1,8 olguda otoimmün tiroidit, \%2,7 olguda Down sendromuydu. Tiroid otoantikorları olguların $\% 0,9^{\prime}$ unda yüksekti. Olguların \%4,5'inde hipotiroidi, \%0,9'unda hipertiroidi saptandı. Olguların \%24,5'ine topikal kortikosteroid losyon, \%30,9'una antralin, \%0,9'una minoksidil \%2'lik losyon, \%0,9'una kalsipotriol losyon, \%1,8'ine topikal kalsinörin inhibitörü, \%10'una intralezyonel kortikosteroid tedavisi verildi. Topikal tedaviye dirençli \%15,4 olguda sistemik kortikosteroid ve PUVA tedavisine geçildi. Olguların \%14,5'inde topikal tedaviler değişik kombinasyonlarda kullanıldı. Olguların \%34,5'inde remisyon gözlendi. Ortalama remisyon süresi 12,2 aydı. Olguların \%26,3'ünde ortalama 2 kez nüks gözlendi.

Sonuç: Sonuçlarımızın, ülkemizdeki AA'lı çocuk olguların epidemiyolojik verilerine katkıda bulunacağını düşünüyoruz. (Türkderm 2013; 47: 15860)

Anahtar Kelimeler: Alopesi areata, çocukluk çağı

\section{Summary}

Background and Design: Approximately $20 \%$ of alopecia areata (AA) cases are children. There is limited information about childhood AA. We aimed to examine demographic features, treatments and prognosis of children with AA followed in our clinic

Materials and Methods: We retrospectively analyzed the records of 110 AA patients 16 years of age or older. Data on age, gender, age at disease onset, duration of the disease, types of AA and onset area, nail involvement, accompanying systemic and dermatological diseases, laboratory tests, treatments and the prognosis, and follow-up period were evaluated.

Results: $46.4 \%$ of subjects were female and $53.6 \%$ were male.The mean age was 10.35 years. The age at disease onset was 8.65 years. Primary onset areas of AA were: scalp in $83.6 \%$ of patients, - eyebrows - in $5.4 \%$, - body hair - in $5.4 \%$, - eyelashes - in $2.7 \%$, and eyebrows and eyelashes in $2.7 \%$ of patients. Types of the disease were: AA in $73,4 \%$ cases, - alopecia totalis -in 19\%, - alopecia universalis - in $5.4 \%$, and ophiaisis in $1.8 \%$ of subjects. Nail involvement and nevus flammeus were observed in $36.3 \%$ and $27 \%$ of subjects, respectively. The mean disease duration was 17.02 months. The accompanying dermatoses were: vitiligo in $2.7 \%$ of cases and atopic dermatitis in $6.3 \%$ of cases. The accompanying systemic diseases were: autoimmüne thyroiditis and Down syndrome in in $1.8 \%$ and $2.7 \%$ of patients, respectively. Thyroid autoantibodies were found to be high in $0.9 \%$ of subjects. We have treated $24.5 \%$ of patients with topical corticosteroid lotion, - $30.9 \%$ - with anthralin, $-0.9 \%$ - with $2 \%$ minoxidil lotion, $-0.9 \%$ - with calcipotriol lotion, $-1.8 \%$ - with topical calcineurin inhibitors, and $10 \%$ of cases with intralesional corticosteroids. We have treated $15.4 \%$ of subjects, who were resistant to topical treatment, with systemic corticosteroids and PUVA therapy. $14.5 \%$ of patients received different combinations of topical treatments. Remission was observed in $34.5 \%$ of cases. The mean remission duration was 12.2 months. On average, two relapses occurred in $26.3 \%$ of subjects.

Conclusion: We assume that our results will contribute to epidemiologic data on childhood AA in our country. (Turkderm 2013; 47: 158-60)

Yazışma Adresi/Address for Correspondence: Dr Munise Daye, Necmettin Erbakan Üniversitesi Meram Tip Fakültesi, Deri ve Zührevi Hastallklar Anabilim Dall, Konya, Türkiye Tel.: +90 3322237912 E-posta: dr_munise@yahoo.com Geliş Tarihi/Received: 29.11.2012 Kabul Tarihi/Accepted: 04.02.2013 


\section{Giriş}

Lokalize ve skar bırakmayan alopesilerin en sık görülen formu alopesi areata $(A A)^{\prime}$ dır. Genetik yatkınlıkla birlikte çevresel tetikleyici faktörlerin rol aldığı, organa özgü otoimmün bir hastalık olduğu düşünülmektedir1,2. Hastalık, hem erişkin hem de çocukları etkiler. Ancak çocukluk çağında görülen AA ile ilgili bilgiler sınırlıdır. Çalışmamızda, Konya ili ve ilçelerinde yaşamakta olan ve kliniğimizde AA tanısıyla takip edilen çocuk olguların demografik özellikleri, hastalık tedavi ve takiplerindeki özellikler sunulmaktadır.

\section{Gereç ve Yöntem}

2006-2012 yılları arasında saç polikliniğimize başvurarak teşhis ve tedavileri yapılan, yaşları 16 ve altında olan 110 AA olgusuna ait veriler geriye dönük olarak incelendi. Olguların yaş, cinsiyet, hastalık başlangıç yaşı, hastalık süresi, alopesi tipi ve başlangıç yeri, tırnak bulguları, nevus flammeus varlığı, aile öyküsü, otoimmün hastalığı, tetikleyici faktörleri, eşlik eden dermatoz veya sistemik hastalık varlığı, tam kan sayımı, biyokimya ve tiroid fonksiyon testleri, AA tedavileri ve takip eden yıllardaki seyirlerine ait bilgiler değerlendirildi. AA tipi alopesi areata (AA), alopesi totalis (AT), alopesi universalis (AU) ve ofiyazis olarak belirlendi.

\section{Bulgular}

Hastalığı 16 yaşından önce başlayan 110 olgu çalışmaya dahil edildi. Klinik bulguları Tablo 1'de gösterilmektedir. Olgularımızın \%53,6'sı erkek, \%46,4'ü kadındı. Olgularımızın başvuru anındaki yaş ortalamaları 10,35 yıl (1-16 yaş) idi. Yaş ortalaması erkekler için 9,9 (1-16 yaş) yıldı, kadınlar için 10,6 (4-16) yıldı. AA başlangıç yaşı ortalama 8,65 yıldı. Erkekler için 6,3 (6 ay-16 yıl) yılken, kadınlar için 9,7 (4 yaş-15) yıldı. Hastalık süresi ortalama 17,02 aydı. Erkekler için 21,2 ayken (1 hafta-10 yıl), kadınlar için 15,8 aydı (2 hafta-9,5 yıl). E/K oranı 1,15/1 'di. Olguların \%20,9'unda aile öyküsü mevcuttu. Olgularımızın \%36,3'ünde tırnak tutulumu mevcuttu. En sık yüksük tırnak \%11, trakiyonişi \%8,1, çizgilenme artışı \%8,1, lökonişi \%6,3 ve birer olguda onikoliz, mediyan tırnak distrofisi, onikotillomani, melonişi saptandı. Nevus flemmus $\% 2,7$ olguda mevcuttu. Olgularımızın eşlik eden dermatoz ve sistemik hastalıkları Tablo 2'de gösterilmektedir. Olguların \%35,4'ünde stres tetikleyici faktördü. Olguların laboratuvar tetkiklerinde $\% 43,6$ sında ferritin düşüklüğü, \%22,7'sinde anemi, \%2,7'sinde B12 vitamin eksikliği, $\% 1,8$ 'inde tiroid otoantikorlarının pozitifliği saptandı. Olgularımıza

\section{Tablo 1. Olguların klinik bulguları}

\begin{tabular}{|l|c|c|c|}
\hline AA başlangıç yeri & \multicolumn{1}{|c|}{ Erkek } & \multicolumn{1}{c|}{ Kadın } & Toplam \\
\hline Skalp & $55(\% 50)$ & $37(\% 33,6)$ & $92(\% 83,6)$ \\
\hline Kaş & $2(\% 1,8)$ & $4(\% 3,6)$ & $6(\% 5,4)$ \\
\hline Vücut kılları & $3(\% 2,7)$ & $3(\% 2,7)$ & $6(\% 5,4)$ \\
\hline Kirpik & $1(\% 0,9)$ & $2(\% 1,8)$ & $3(\% 2,7)$ \\
\hline Kaş ve kirpik & $1(\% 0,9)$ & $2(\% 1,8)$ & $3(\% 2,7)$ \\
\hline AA tutulum şekli & & & \\
\hline AA & $43(\% 39,1)$ & $38(\% 34,5)$ & $81(\% 73,6)$ \\
\hline A.Totalis & $10(\% 9,01)$ & $11(\% 10)$ & $21(\% 19)$ \\
\hline A.Universalis & $5(\% 4,5)$ & $1(\% 0,9)$ & $6(\% 5,4)$ \\
\hline Ofiyazis & $1(\% 0,9)$ & $1(\% 0,9)$ & $2(\% 1,8)$ \\
\hline AA: Alopesi areata & \multicolumn{3}{|l}{} \\
\hline
\end{tabular}

verilen tedaviler Tablo 3'te yer almaktadır. Olguların \%34,5'inde remisyon gözlendi. Ortalama remisyon süresi 12,2 ay olarak saptandı. Olguların \%26,3’ünde ortalama 2 kez nüks gözlendi.

\section{Tartışma}

Literatürde AA'nın \%20-50'sinin çocukluk çağında ortaya çıktığı belirtilmektedir. Pediyatrik grupta $A A^{\prime}$ nın klinik özellikleri ve seyri hakkında yeterli bilgi bulunmamaktadır3,4. Erkek çocuklarda biraz daha fazla görüldüğü bildirilmiştir. Bazı çalışmalarda erkek cinsiyette, bazı çalışmalarda ise kadın cinsiyette daha şiddetli tutulum saptanmış olup cinsiyet ve şiddet arasındaki net ilişki aydınlatılamamıştır ${ }^{5-9}$ Çalışmamızda hastaların \%53,6'sı erkek olup, E/K oranı 1,15/1 idi. Daha önce yapılan çalışmalarda 6 yaşından önceki çocuklarda AA'nın nadir olarak gözlendiği bildirilmiştir4,10. Olgularımızda hastalığın başlama yaşı 8,65 yıl olarak saptandı. Olgularımızın başvuru anındaki yaş ortalaması 10,3 yıldı. Olgularımızın hastalık süresi ortalama 17,02 aydı ve yapılan çalışmalarla uyumluydu 3,11 . Kılınç ve ark. çalışmasında; $A A$ ve $A T^{\prime}$ in en çok görülen klinik tip olduğu bildirilmiştir ${ }^{11}$. Olgularımızın \%75,4'ünde AA, \%19'unda AT gözlendi. Özdemir ve ark. çalışmasında ofiyazik tutulum \%41,6 gibi yüksek bir oranda görülürken, çalışmamızda olguların \%1,8'inde ofiyazis saptandı4. Literatürlerde çocukluk çağında ortaya çıkan ve ofizaisi olan AA olgularının prognozunun daha kötü olduğu ifade edilmektedir12. Yapılan çalışmalarla uyumlu olarak; olgularımızda AA başlangıç yeri en sık skalp $(\% 83,6)$, ikinci sıklıkta

Tablo 2. Olguların eşlik eden dermatoz, eşlik eden sistemik
hastalık
\begin{tabular}{|c|c|c|c|}
\hline & Erkek & Kadın & Toplam \\
\hline Ek dermatoz & & & \\
\hline Atopi & $16(\% 14,5)$ & $14(\% 12,7)$ & $30(\% 27,2)$ \\
\hline Atopik dermatit & $5(\% 4,5)$ & $2(\% 1,8)$ & $7(\% 6,3)$ \\
\hline Vitiligo & $1(\% 0,9)$ & $2(\% 1,8)$ & $3(\% 2,7)$ \\
\hline Ek sistemik hastalık & & & \\
\hline Otoimmün tiroidit & $1(\% 0,9)$ & $1(\% 0,9)$ & $2(\% 1,8)$ \\
\hline Down sendromu & $2(\% 1,8)$ & $1(\% 0,9)$ & $3(\% 2,7)$ \\
\hline Hipotiroidi & $3(\% 2,7)$ & $2(\% 1,8)$ & $5(\% 4,5)$ \\
\hline Hipertiroidi & - & $1(\% 0,9)$ & $1(\% 0,9)$ \\
\hline Diyabet & $2(\% 1,8)$ & $1(\% 0,9)$ & $3(\% 2,7)$ \\
\hline
\end{tabular}

Tablo 3. Olgulara uygulanan tedaviler

\begin{tabular}{|l|c|c|c|}
\hline & \multicolumn{1}{|c|}{ Erkek } & Kadın & Toplam \\
\hline Tedavi & & & \\
\hline Topikal kortikosteroid & $10(\% 9,1)$ & $17(\% 15,4)$ & $27(\% 24,5)$ \\
\hline Antralin & $21(\% 19,01)$ & $13(\% 11,8)$ & $34(\% 30,9)$ \\
\hline Minoksidil & $1(\% 0,9)$ & - & $1(\% 0,9)$ \\
\hline Kalsipotriol & $1(\% 0,9)$ & - & $1(\% 0,9)$ \\
\hline $\begin{array}{l}\text { Topikal kalsinörin } \\
\text { inhibitörleri }\end{array}$ & $1(\% 0,9)$ & $1(\% 0,9)$ & $2(\% 1,8)$ \\
\hline İntralezyonel steroid & $4(\% 3,6)$ & $7(\% 6,3)$ & $11(\% 10)$ \\
\hline Sistemik kortikosteroid & $8(\% 7,2)$ & $7(\% 6,3)$ & $15(\% 13,6)$ \\
\hline PUVA & $1(\% 0,9)$ & $1(\% 0,9)$ & $2(\% 1,8)$ \\
\hline Kombinasyon & $9(\% 8,1)$ & $7(\% 6,3)$ & $16(\% 14,5)$ \\
\hline
\end{tabular}


kaş $(\% 5,4)$ ve $(\% 5,4)$ vücut kılları olarak saptandı13,14. Literatürde tırnak tutulum oranlarının çok farklı olması; tırnak değişikliklerinin asemptomatik olmasından dolayı kayıt edilmemesine bağlanmaktadır 4 Çalışmamızda \%36,3 olguda tırnak tutulumu saptandı ve literatürlerle uyumlu olarak en sık yüksük tırnaktı $(\% 10)^{13,15}$. Yapılan çalışmalarda şiddetli ve kronik AA olgularında, nevüs flammeus birlikteliğinin daha sık gözlendiği ifade edilmiştir4,16. Olgularımızın \%2,7'sinde nevüs flammeus saptandı. Pozitif aile öyküsü literatürlerde $\% 4,6$ ile $\% 42$ arasında değişmektedir4,5,17,18. Olgularımızın \%20,9'unda aile öyküsü pozitifti. Literatürlerde AA'nın alevlenme ve remisyon dönemlerinde psikolojik stresin önemli rol oynadığı bildirilmiştir. Çeşitli çalışmalarda \%596 oranlarında AA'nın stresle tetiklendiği bildirilmiştir13,19,20. Tetikleyici olarak olgularımızın \%35,4'ünde stres faktörü pozitif saptandı. AA'nın diğer hastalıklarla ilişkisi ile ilgili az sayıda literatür vardır. Özellikle çeşitli otoimmün hastalıklarla ilişkisi \%5-17,5 oranında bildirilmiştir3,21,22. En sık birlikte görüldüğü hastalıklar atopi, tiroid hastalıkları ve vitiligodur. $\mathrm{AA}^{\prime} \mid$ । olgularda tiroid hastalığı ve vitiligo sıklığı \%1-20 olarak bildirilmiş̧ir4,8. Olgularımızın \%27,2'sinde atopi saptandı. Literatürlerde AA ve atopi birlikteliği \%10-52 arasında bildirilmiştir. Atopi ilişkili olgularda hastalık daha erken başlamakta, uzun ve şiddetli seyir göstermektedir13. Eşlik eden dermatoz olgularımızın \%2,7'sinde vitiligo, \%6,3'ünde de atopik dermatitti. Eşlik eden sistemik hastalıklar olguların \%1,8'inde otoimmün tiroidit, \%4,5'inde hipotiroidi, \%0,9'unda hipertiroidi, \%2,7'sinde Down sendromuydu. Nanda ve ark. çalışmasında eşlik eden otoimmün tiroid hastalığı ve Down sendromu yüzdesi eşit ve \%1,4 olarak bulunmuştur ${ }^{13}$ AA olgularının serum hemoglobin, ferritin, vitamin B12 ve folik asit düzeylerini inceleyen çalışmaların çoğunda anemiyle birliktelik saptanmış, B12 ve folik asit düzeyleri normal sınırlarda bulunmuştur23. Yapılan laboratuvar tetkiklerinde; olgularımızın \%43,6'sında ferritin eksikliği, \%22,7'sinde anemi, \%2,7'sinde açlık kan şekeri yüksekliği, $\% 2,7^{\prime}$ sinde B12 vitamin eksikliği saptandı.

AA tedavisinde çok çeşitli ajanlar kullanılmaktadır. Çocuklarda tedavi seçiminde hastalığın şiddeti ve çocuğun tedaviye toleransı önem taşı 4 . Özellikle hafif şiddetteki tutulumlarda spontan remisyon oranının yüksek oluşu tedaviye yanıtı değerlendirmeyi güçleştirir. Şiddetli tutulumun olduğu olgularda birçok tedaviye direnç söz konusudur. Güncel yayınlarda hafif ve orta şiddetli AA tedavisinde öncelikli olarak potent topikal steroidler veya intralezyonel kortikosteroid tedavisi, daha yaygın ve şiddetli tutulumun olduğu AA olgularında kontakt immünoterapi ve peruk kullanımı önerilmektedir. Antralin, minoksidil ve kalsipotriol de lokalize lezyonlarda dermatologlar tarafından sık kullanılan ajanlardır. Şiddetli tutulumun olduğu olgularda sistemik steroid, fotokemoterapi, immünsupresif tedaviler ve biyolojik ajanlar kullanılmaktadır ${ }^{12}$. Hafif- orta şiddette tutulumu olan olgularımızın $\% 24,5^{\prime}$ ine topikal kortikosteroid losyon, \%30,9'una antralin, \%0,9'una minoksidil \%2'lik losyon, \%0,9'una kalsipotriol losyon, \%1,8'ine topikal kalsinörin inhibitörü, \%10'una intralezyonel kortikosteroid tedavisi verildi. AA'da sistemik steroid tedavisinin veriliş protokolleri hakkında görüş birliği yoktur. Yapılan çeşitli çalışmalarda sistemik steroid tedavisi ile \%25-60 oranlarında yeni kıl çıkışı olduğu bildirilmiştir4. Olgularımızdan topikal tedaviye istenilen yanıtın alınamadığı ve şiddetli tutulumun olduğu \%15,4 olguda sistemik kortikosteroid ve PUVA tedavisine geçildi. Olgularımızın \%14,5'ine topikal tedaviler değişik kombinasyonlarda (antralin ve topikal steroid, minoksidil ve topikal steroid, kalsipotriol ve topikal steroid) kullanıldı. Tedavi altındaki olgularımızın \%34,5'inde remisyon gözlendi. Ortalama remisyon süresi 12,2 ay olarak saptandı. Hastalığın seyrinde spontan remisyonlar da görüldüğü için verilen tedavilerin sonuçlarını değerlendirmek zordur ${ }^{4}$ Takiplerinde olgularımızın \%26,3'ünde ortalama 2 kez nüks gözlendi.

\section{Sonuç}

Çalışmamızda bölgemizde yaşayan alopesi areatalı çocuk olguların demografik ve klinik özellikleri, olguların tedavileri ve tedaviye yanıtları ile ilgili bilgileri değerlendirilmiştir. Sonuçlarımızın literatürle uyumlu olduğunu, ülkemizin epidemiyolojik verilerine katkıda bulunacağını düşünüyoruz.

\section{Kaynaklar}

1. Messenger R, Simpson N: Alopecia areata. In: Dawber R. Ed. Diseases hair and scalp. Oxford: Blackwell Science Ltd, 1997:338-69.

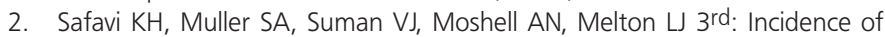
alopecia areata in Olmsted County, Minnesota, 1975 through 1989. Mayo Clin Proc 1995;70:628-33.

3. Özden MG, Bayramoğlu NE, Aydın F, et al: Çocukluk çağı alopesi areata hastalarının klinik özellikleri ve seyri Turk J Dermatol 2010;4:60-5.

4. Özdemir M, Engin B, Baysal İ, Mevlitoğlu İ: Çocukluk çağında başlayan alopesi areatanın klinik özellikleri. Türkiye Kinikleri J Dermatol 2007:17:15-20.

5. Sharma VK, Dawn G, Kumar B: Profile of alopecia areata in Northern India Int J Dermatol 1996:35:22-7.

6. Muller SA, Winkelmann RK: Alopecia Areata: an evaluation of 736 patients Arch Dermatol 1963:88:290-7.

7. van der Steen $P$, Traupe H, Happle R, et al: The genetic risk for alopecia areata in first degree relatives of severely affected patients. An estimate. An estimate. Acta Derm Venereol 1992;72:373-5.

8. Tan E, Tay YK, Giam YC: A clinical study of childhood alopecia areata in Singapore. Pediatr Dermatol 2002;19:298-301.

9. Xiao FL, Yang S, Liu JB, et al: The epidemiology of childhood alopecia areata in China: a study of 226 patients. Pediatr Dermatol 2006:23:13-8.

10. Güneş AT: Fiziksel etmenlere bağlı dermatozlar. Dermatoloji.Ed. Tüzün Y, Kotoğyan A, Aydemir EH, Baransü O, editörler. İstanbul, Nobel Tıp Kitabevleri, 1994;61-5

11. Kılınç I, Alper S, Ceylan C, Ünal İ: Alopesi areatalı olgularda hasta profili: Bir retrospektif çalışma. Ege Tıp Dergisi 2002;41:25-7

12. Messenger AG, McKillop J, Farrant $P, M c D o n a g h ~ A J$, Sladden $M$ : British Association of Dermatologists' guidelines for the management of alopecia areata 2012. Br J Dermatol 2012;166:916-26.

13. Nanda A, Al-Fouzan AS, Al-Hasawi F: Alopecia areata in children: a clinical profile. Pediatr Dermatol 2002;19:482-5.

14. Polat $M$, Parlak AH, Şereflican B: Dermatoloji kliniğinde görülen alopesi areatalı hastaların klinik ve epidemiyolojik özellikleri. Göztepe Tıp Dergisi 2010;25:86-90,

15. Rocha J, Ventura F, Vieira AP, et al: Alopecia areata: a retrospective study of the paediatric dermatology department (2000-2008). Acta Med Port 2011;24:207-14

16. Akhyani $M$, Farnaghi $F$, Seirafi $H$, et al: The association between nuchal nevus flammeus and alopecia areata: a case-control study. Dermatology 2005:211:334-7.

17. Yang S, Yang J, Liu JB, et al: The genetic epidemiology of alopecia areata in China. Br J Dermatol 2004;151:16-23.

18. Blaumeiser B, van der Goot I, Fimmers R, et al: Familial aggregation of alopecia areata. J Am Acad Dermatol 2006;54:627-32

19. Díaz-Atienza F, Gurpegui M: Environmental stress but not subjective distress in children or adolescents with alopecia areata. J Psychosom Res 2011;71:102-7.

20. Wang E, McElwee KJ: Etiopathogenesis of alopecia areata: Why do our patients get it? Dermatol 2011;24:337-47.

21. Shellow WV, Edwards JE, Koo JY: Profile of alopecia areata: a questionnaire analysis of patient and family. Int J Dermatol 1992;31:186-9.

22. Werth VP, White WL, Sanchez MR, Franks AG: Incidence of alopecia areata in lupus erythematosus. Arch Dermatol 1992;128:368-71.

23. Ertugrul DT, Karadag AS, Takci Z, et al: Serum holotranscobalamine, vitamin B12, folic acid and homocysteine levels in alopecia areata patients. Cutan Ocul Toxicol 2013;32:1-3. 